\title{
On Frankincense \\ (Olibanum, Boswellia spp., Burseraceae)
}

\section{Zoran Maksimović*}

University of Belgrade - Faculty of Pharmacy, Department of Pharmacognosy, Vojvode Stepe 450, 11221 Belgrade, Serbia

*Coresponding author: E-mail: zmaksim1@pharmacy.bg.ac.rs

\section{Summary}

Boswellia species (Burseraceae) are trees or shrubs whose area of distribution covers the wide geographic area between North Africa and India. After incision, their bark produces oleogum resin known as frankincense (Olibanum). In traditional medicine, frankincense is often used for medical treatment of arthritis, asthma, ulcerative colitis, coughs, sores, and wound healing. Various frankincense preparations are marketed almost exclusively as dietary supplements. Indian frankincense, or Olibanum indicum, is official in the European Pharmacopoeia.

The major components of frankincense are boswellic acids, among which the most important and abundant is 3-O-acetyl-11-keto- $\beta$-boswellic acid (AKBA). AKBA is a 5-lipoxygenase inhibitor with anti-inflammatory and anti-arthritic effects. Besides, frankincense contains essential oil, whose composition greatly depends on the biological source, as well as arabinogalactans and glycoproteins.

In small clinical trials, certain benefits of various frankincense preparations have been demonstrated in cases of ulcerative colitis, bronchial asthma, mild symptoms of irritable bowel syndrome, and various disorders of osteo-muscular system. However, for collagenous colitis and Crohn's disease remission maintenance, the evidence is ambiguous or negative. AKBAcontaining extract was found advantageous in patients with osteoarthritis, and to some extent with rheumatoid arthritis. Almost all the trials had serious flaws in experimental design, such as insufficient sample size and/or incomplete reporting of data. For any clinical recommendation of frankincense preparations, larger and better-designed studies are needed.

Key words: Boswellia, frankincense, boswellic acids, anti-inflammatory.

DOI: https://doi.org/10.5937/arhfarm71-29280 


\section{Introduction}

Frankincense, Gummi Boswellii or Olibanum, is an oleo-gum resin whose biological source are as many as 24 plant species (out of 25) belonging to the genus Boswellia (family Burseraceae). Representatives of this genus are distributed across the huge geographic area between the tropical regions of Africa and arid forests of Punjab and West Bengal in India (1-4). Oleo-gum resin of one of the most important and bestknown species of this genus, $B$. sacra, was brought to the eastern Mediterranean by the so-called "incense trade route" - the oldest caravan route in the world, which included a network of ancient land and sea trading routes linking the Mediterranean empires with the southern and eastern sources of fragrant substances, spices, and luxury goods $(1,4)$. It stretched from Mediterranean ports across the Levant and Egypt through North Africa to Yemen and Oman in the Arabian Peninsula, as well as to India and even beyond. The frankincense trade flourished between the $3^{\text {rd }}$ century BC and the $2^{\text {nd }}$ century AD (5).

Frankincense is most often produced by incising the bark of $B$. serrata Roxb. ex Colebr. from India, B. sacra Flueck. (syn. B. carterii Birdw.), which grows in the Middle East and the Arabian Peninsula, $B$. frereana Birdw. from the region of Northeast Africa (Somalia and Ethiopia), B. papyrifera (Caill. ex Delile) Hochst. and B. rivae Engl. (Ethiopia), as well as B. neglecta S. Moore (Eritrea) (6).

The milky exudate that drips out of the incision is whitish in the beginning and gradually hardens in contact with air, changing its color as well. It is collected throughout the year and marketed, fresh or dried, in the form of fragrant, small, ovoid pieces similar to drops, reddish-brown, greenish-yellow, dull yellow or yellow-orange in color. Pieces of oleo-gum resin are sometimes agglomerated into chunks up to $5 \mathrm{~cm}$ long and up to $2 \mathrm{~cm}$ thick. The fracture is smooth, waxy and translucent. It burns readily and emits an agreeable characteristic balsamic resinous odor. Most of the frankincense in trade comes from Oman, Yemen, and Somalia $(7,8)$.

\section{Chemical Composition}

Frankincense contains 5-9\% of essential oil, whose composition varies in relation to the biological source, $65-85 \%$ of alcohol-soluble resin and about $20 \%$ of water-soluble gum (a mixture of heteropolysaccharides, polysaccharides and polymeric substances) (9).

\section{Essential oil}

Essential oil obtained by distillation of $B$. sacra oleo-gum resin is the most investigated so far. It appears as pale yellowish, fragrant oil lighter than water, whose principal constituent (up to 60\%) is identified as octyl acetate. The others are, in order of descending quantities, 1 -octanol (11.9\%), $\alpha$-pinene (10.9\%), verticilla-4(20),7,11-triene $(6.0 \%)$, incensol acetate $(2-3 \%)$, bornyl acetate $(2.2 \%)$, cembrene A $(2.1 \%)$, linalool $(2.1 \%), \alpha$-thujene $(1.7 \%), E$ - $\beta$-ocimene $(1.7 \%)$, limonene $(1.5 \%), p$-cymene $(1.4 \%)$, 1,8 -cineole $(1.2 \%)$, incensol $(1.0 \%)$, camphene $(1.0 \%)$, sabinene $(0.7 \%), \beta$-pinene 
$(0.7 \%)$, myrcene $(0.5 \%), \alpha$-pinene epoxyde $(0.5 \%), Z$ - $\beta$-ocimene $(0.4 \%)$, trans-verbenol $(0.4 \%)$, terpinene-4-ol $(0.4 \%)$, geranyl acetate $(0.4 \%)$, hexyl acetate $(0.3 \%), E$-nerolidol $(0.2 \%)$ and cembrene $\mathrm{C}(0.1 \%)(7,9)$.

The most abundant compound of essential oil of $B$. serrata oleo-gum resin is $\alpha$ pinene (up to $45 \%$ ). Its distillate is a colourless oil with a significant share of $\alpha$-thujene $(12 \%)$, along with methylchavicol (11.6\%), myrcene (3.8\%), sabinene $(2.2 \%)$, methyleugenol $(2.1 \%)$, germacrene D $(2.0 \%)$, cembrenol $(1.9 \%)$, limonene $(1.9 \%)$, $\alpha$-phellandrene (1\%), $p$-cymene (1\%), linalool $(0.9 \%)$, kessane $(0.9 \%), \beta$-pinene $(0.7 \%)$, perillene $(0.5 \%)$ and cembrene A $(0.5 \%)(7,9)$.

\section{Resin}

The main constituents of frankincense resinous fraction are triterpenoid boswellic acids (more than 12 compounds), among which the most important are 11-keto- $\beta$ boswellic acid (KBA), 3- $O$-acetyl-11-keto- $\beta$-boswellic acid (AKBA), $\alpha$ - and $\beta$-boswellic acid ( $\alpha$ - and $\beta$-BA) and their acetyl derivatives (3-O-acetyl- $\alpha$-boswellic acid and 3-Oacetyl- $\beta$-boswellic acid) (Figure 1). Crude oleo-gum resin typically contains up to $30 \%$ boswellic acids in total, while ethanol extract of frankincense contains up to $43 \%$ boswellic acids $(7,9)$.

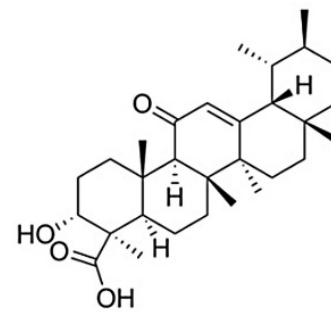

11-keto- $\beta$-boswellic acid

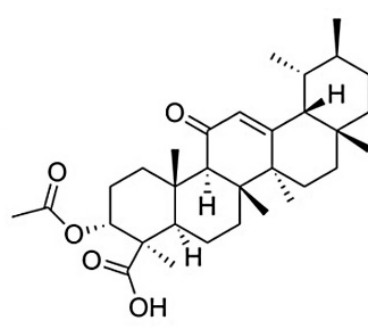

3-O-acetyl-11-keto$\beta$-boswellic acid

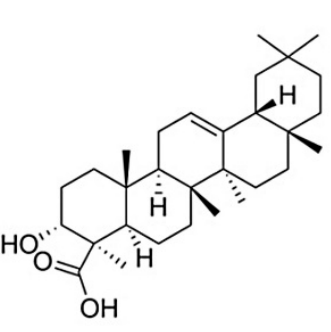

$\alpha$-boswellic acid

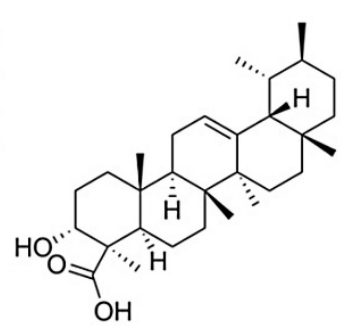

$\beta$-boswellic acid

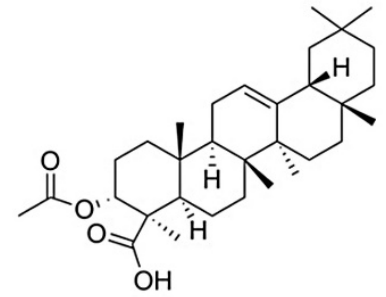

3-O-acetyl- $\alpha$-boswellic acid

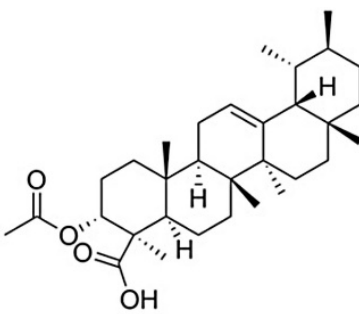

3-O-acetyl- $\beta$-boswellic acid

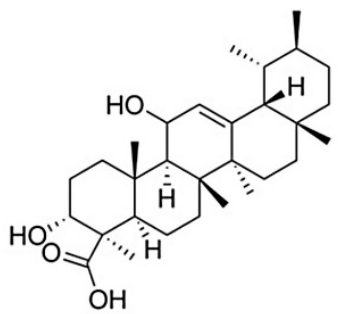

11-hydroxy boswellic acid

Figure 1. Boswellic acids

Slika 1. Bosvelinske kiseline 


\section{Heteropolysaccharides, polysaccharides and polymeric substances}

Major constituents (32-56\%) of this fraction, obtained from B. sacra and B. serrata oleo-gum resin, are arabinogalactans, whose molecular backbone mainly consists of D-galactose units $(\sim 60 \mathrm{~mol} \%)$, with branching through positions 3 and 6 . Side chains are composed mostly of glucuronic acid $(\sim 9 \mathrm{~mol} \%)$ and arabinose (2-14 mol\%), with $4-O$-methyl-glucuronic acid $(13-26 \mathrm{~mol} \%)$ as the terminal molecule $(7,9)$.

Beside arabinogalactans, frankincense contains glucoproteins, whose carbohydrate part almost entirely consist of L-arabinose $(\sim 90 \mathrm{~mol} \%)$ and D-galactose $(8 \mathrm{~mol} \%)$. Arabinose units have been found to make 1,2 and, in smaller amounts, 1,3 bonds and form chains with a high content of terminal arabinose units. On the other hand, the protein part of the glucoprotein molecule contains high share of hydroxyproline $(\sim 50 \mathrm{~mol} \%)$ and serine $(\sim 20 \mathrm{~mol} \%)$. It should be underlined that $B$. serrata gum is richer in proteins $(22 \%)$ than $B$. carterii (6\%). (9)

\section{Traditional use}

Throughout the long history of its use, frankincense has been most commonly used in religious rituals, by incineration and inhalation of its white, fragrant smoke, with the aim of improving emotional well-being and achieving "higher levels of spirituality and improving mental perception, meditation, prayer and awareness" (1-4).

The oleo-gum resin of both B. sacra and B. serrata, as the most important biological sources of frankincense, has been used in cosmetics since ancient times. A black pigment $k o h l$ was made from carbonized frankincense and used by Egyptian women as paint for their eyelids; also in eye washes, for soothing sore eyes, etc. The oleo-gum resin of $B$. sacra has also been used to reinvigorate the skin, to make hair-removal preparations, and in formulation of various fragrances for personal care. Even in modern times, some lines of skin care and cosmetic products contain frankincense for treatment of different skin imperfections $(1,3)$.

Medieval Persian physician and polymath Ibn Sina (Avicenna, 980-1037 AD) recommended the use of frankincense for dysentery, fever, tumors, ulcers and vomiting. Information on the use of frankincense as digestive, purgative, diuretic, for teeth and gum support, to enhance memory and to alleviate emotional and psychological problems, also came from the Middle East and spread worldwide (3).

$B$. serrata oleo-gum resin has been used in Ayurveda and Unani medical systems in India against a whole array of health disorders, such as diarrhea, dysentery, ringworm infestations, boils, fever (as an antipyretic), skin, blood and cardiovascular diseases, inflammations of the esophagus, larynx and oral cavity mucosa, as well as with claims of benefit in respiratory ailments (bronchitis, asthma, cough), irregular vaginal secretion and menstrual cycle, loss of hair, jaundice, hemorrhoids, syphilis, and liver ailments. It has also been used as a diaphoretic, astringent, diuretic and both as an internal and external stimulant (10). In traditional Chinese medicine (TCM), frankincense is used per os to 
promote blood circulation, relax muscles, and mitigate discomfort in menstrual disorders, as well as against pain. Listed in ancient medical compendia as ru xiang, it is also used externally to reduce swelling in lesions and to promote wound healing (3). In Africa, frankincense is largely recommended by herbalists as a tonic, diuretic, as well as against syphilis and bilharzia (schistosomiasis) (3).

\section{Modern use of frankincense}

For pre-marketing authorization and product licensing purposes, Canadian Natural Health Products Directorate (NHPD) has published three monographs that define the conditions for oromucosal, oral, and topical use of frankincense and/or its preparations. According to the NHPD, oral administration of dried Boswellia oleo-gum resin is permitted as an astringent, diuretic, to relieve nervous tension; in TCM, to improve the life energy $(q i)$ flow, to alleviate urinary disorders, and to eliminate damp wind. The allowed indications for topical use in TCM are the treatment of carbuncles, improvement of tissue regeneration, treatment of injuries, alleviation of problems with the gums, teeth, oral cavity and throat, as well as the alleviation of pain, promotion of sore healing, and reduction of swelling (3).

\section{Frankincense in contemporary pharmacopoeias}

B. serrata oleo-gum resin and extract have been official in the United States Pharmacopoeia since December $1^{\text {st }}, 2010$, when corresponding monographs were published in the $2^{\text {nd }}$ Supplement to the United States Pharmacopeia, $33^{\text {rd }}$ Revision National Formulary $28^{\text {th }}$ edition (USP 33 NF 28) (3). For Indian frankincense (Olibanum indicum), an official monograph was published in the European Pharmacopoeia 8.0 (Ph. Eur. 8.0), where this substance is described as "Air-dried gum-resin exudate, obtained by incision in the stem or branches of Boswellia serrata Roxb. ex Colebr." (11).

\section{Use of frankincense in food and cosmetic industry}

The essential oil, obtained by hydrodistillation from the oleo-gum resin of $B$. carterii and other Boswellia species (referred to as "Olibanum Oil"), has been regulated as a food additive in the USA since June 2010 (Food Chemicals Codex) and permitted for direct addition to food for human consumption (3). It is used in the food industry as an additive to meat products, various beverages (both alcoholic and non-alcoholic), pastries, frozen dairy products, etc. Frankincense extract and oil are also used in the cosmetic industry as fragrance fixatives or scent ingredients, in personal care products (soaps, creams, lotions and perfumes), usually in a concentration of $0.8 \%$ (12). 


\section{Frankincense in the treatment of peritumoral oedema derived from brain tumours}

An orphan designation $(\mathrm{EU} / 3 / 02 / 117 ; 2002)$ was granted by the European Commission to Pharmasan GmbH (Freiburg, Germany) for B. serrata resin extract for the treatment of peritumoral oedema derived from brain tumours (13).

Uncontrollable tumour growth in brain tissues causes an abnormal build-up of fluids, with consequent swelling of the peritumoral tissues (peritumoral oedema). It causes an increase in intracranial pressure, which leads to brain compression and manifestation of symptoms related to the dysfunction of the affected regions. Peritumoral oedema is life-threatening, so therapy is obligatory (13). Glucocorticoids were authorised as the drugs of choice for the treatment of peritumoral oedema in the European Community in 2002. Although useful for long-term treatment, glucocorticoids are notorious for their serious side effects. $B$. serrata resin extract might offer a better safety profile than glucocorticoids. It blocks the biosynthesis of leukotrienes, which participate in the regulation of the state of blood vessels and lower respiratory passageways, and also affects the activity of white blood cells. Leukotrienes seem to contribute to the development of peritumoral oedema in the brain (13). However, on request of the sponsor, this product was withdrawn from the Community Register of Orphan Medicinal Products in November 2006 (13).

\section{Pharmacology}

\section{Analgesic Activity}

It has been shown that intraperitoneal gavage of the non-phenolic fraction of the crude $B$. serrata oleo-gum resin induced analgesia in $60 \%$ of male albino rats (Haffkine strain) weighing between 125 and $200 \mathrm{~g}$ at a dose of $60 \mathrm{mg} / \mathrm{kg}$ body weight (b.w.). At a dose of $150 \mathrm{mg} / \mathrm{kg}$ b.w., analgesia has been observed in $70 \%$ of rats, as well as a $70 \%$ reduction of spontaneous motoric activity, which lasted for $2 \mathrm{~h}$. The analgetic effect has been found to be proportionate to the activity of $3-4.5 \mathrm{mg} / \mathrm{kg} \mathrm{b}$.w. of morphine. Both the sedative and analgesic effects of the non-polar fraction of $B$. serrata oleo-gum resin were antagonized by the treatment of the animals with sub-analgesic dose of morphine hydrochloride $(7,14)$.

The analgesic effect in rats was tested by both the hot-wire and mechanical compression methods. The non-phenolic fraction was produced by distillation of the $B$. serrata oleo-gum resin; the obtained oil was dissolved in diethyl ether and the phenolic fraction was separated by liquid-liquid extraction with aqueous sodium hydroxide. The ethereal layer (containing the non-phenolic fraction) was successively washed to remove traces of alkaline agents, and the solvent was removed under reduced pressure. The phenolic fraction was separated from the aqueous layer after neutralization with hydrochloric acid and extraction with ether. Both fractions and morphine hydrochloride 
solution were suspended in Polysorbate- 80 and administered intraperitoneally to laboratory animals (14).

\section{Anticomplementary activity}

Anticomplementary activity of boswellic acids has been assessed in vitro via the decrease of immune-induced haemolysis of opsonized sheep erythrocytes by pooled guinea-pig serum. Boswellic acids inhibit the C3-convertase enzyme, which is necessary for the activation of the classical complement pathway, with a threshold of $100 \mu \mathrm{g} / \mathrm{ml}$ (15).

Like the other triterpenic acids of plant origin (i.e. glycyrrhetic, ursolic, oleanolic and crataegolic), $\beta$-boswellic acid expressed a prominent inhibitory activity for both the classical and the alternative complement pathway. At concentrations of between $0.005-$ $0.1 \mathrm{mM}$, a significant decrease of immunohemolysis has been observed in vitro, with an $\mathrm{IC}_{50}$ value of $10 \mu \mathrm{mol} / \mathrm{L}$. (16)

\section{Anti-inflammatory activity}

In vivo assessment of the anti-inflammatory activity of aqueous extract of crude frankincense showed a significant inhibition of both maximal and total oedema response during the span of 6 hours of carrageenan-induced rat paw oedema (7). At 50.0-200.0 $\mathrm{mg} / \mathrm{kg}$ b.w. of oleo-gum resin or aqueous-methanol extract of the gum (9:1), intragastric gavage diminished carrageenan- or adjuvant- (Mycobacterium butyricum suspended in mineral oil) induced paw oedema in rats by $34-73 \%$ (7). At the same dose, an ethanol extract of crude frankincense showed a prominent anti-inflammatory activity in carrageenan-induced oedema in rats and mice, and dextran-induced oedema in rats. A significant antiarthritic activity of the investigated extract was observed; however, it was found ineffective in the case of cotton pellet-induced granuloma test. Finally, the treatment inhibited an increase in serum transaminase levels induced by inflammation, as well as leukocyte counts, but did not show antipyretic or analgesic activity in rats (7).

In vivo anti-inflammatory activity of crude frankincense and isolated boswellic acids was investigated in laboratory animals (rats) with adjuvant-induced arthritis. The animals were treated with $100.0 \mathrm{mg} / \mathrm{kg}$ b.w. of the crude drug preparation or $200.0 \mathrm{mg} / \mathrm{kg}$ b.w. of boswellic acids, applied by intragastric gavage for 2 weeks (7). The activity of $\beta$ glucuronidase was measured to estimate the lysosomes stability. This investigation showed that the treatment of laboratory animals with either the extract or boswellic acid increased lysosomal stability and exerted a protective effect on the integrity of lysosomes. Boswellic acids specifically inhibit the activity of elastase in leukocytes, as well as the proliferation and activity of topoisomerases of leukaemia and glioma cell lines, leading to apoptosis (7).

Methanol extract of crude frankincense, applied topically, markedly inhibited 12-O-tetradecanoylphorbol-13-acetate-induced skin inflammation, epidermal 
proliferation, the number of epidermal cell layers and tumour development induced by 7,12-dimethylbenz[a]anthracene in mice. The addition of the crude drug $(0.2 \% ; 10-24$ weeks) to the diet of CF-1 mice, reduced the growth of parametrial fat pad weight and inhibited azoxymethane-induced formation of aberrant crypt foci (ACF) of morphological changes observed in rodents after the administration of colon-specific carcinogens, such as azoxymethane, by $46 \%$ (7).

\section{Mechanisms of Action}

It is assumed that boswellic acids in general, and 3-O-acetyl-11-keto- $\beta$-boswellic acid (AKBA) in particular, as the most important component of frankincense, contribute the most to the pharmacological activities of this herbal substance. AKBA is involved in the regulation of numerous cellular signaling pathways that initiate various inflammatory diseases and types of tumours; therefore, it is a natural product that is considered potentially useful for the treatment of a large number of diseases, such as arthritis, Crohn's disease, irritable bowel syndrome, psoriasis, glioma, colon cancer, leukaemia, prostate cancer, as a substitute to nonsteroidal anti-inflammatory drugs (NSAIDs). In vitro and animal studies showed that the anti-inflammatory activity of AKBA occurs mainly through inhibition of 5-lipoxygenase (5-LOX) and, to a lesser extent, cyclooxygenase-1 (COX-1). It also inhibits nuclear transcription factor NF- $\kappa \mathrm{B}$, significantly reducing the biosynthesis of a key proinflammatory cytokine, tumour necrosis factor $\alpha(\mathrm{TNF}-\alpha)(8,10,12,17)$.

\section{Inhibition of 5-lipoxygenase}

Investigations on the anti-inflammatory activity of boswellic acids in the light of 5-lipoxygenase (5-LOX) inhibition in laboratory animal models and in vitro, showed that AKBA is particularly active, in a dose-dependent manner. 5-LOX is an enzyme with crucial position in the biosynthesis of proinflammatory products such as 5-hydroxyeicosatetraenoic acid (5-HETE) and leukotriene B4 (LTB4), which are responsible for chemotaxis, bronchoconstriction, and increased vascular permeability. The inhibition of 5-LOX strengthens the hypothesis that AKBA could influence the course of all inflammatory diseases with 5-LOX pathogenesis. The other antiinflammatory ingredients of plants, such as quercetin and similar compounds, also inhibit this enzyme, but more generally, as antioxidants, while boswellic acids appear to act like specific inhibitors of 5-LOX $(2,7,17)$.

\section{Inhibition of human leukocyte elastase}

Levels of 5-LOX and human leukocyte elastase (HLE) increase together in many inflammatory diseases. In vitro, AKBA blocks the HLE activity in a dose-dependent manner, in contrast to the other inhibitors of leukotriene biosynthesis. AKBA exerts a non-competitive mode of HLE blocking, which is a unique feature of this natural product. HLE may be involved in the pathogenesis of emphysema; it stimulates the mucus 
secretion in alveoli and thus may play a role in obstructive, restrictive and chronic lung diseases (12).

\section{Inhibition of $L L-37$}

LL-37 is a peptide that induces cytokine production via a number of immunocompetent and other cells, thus exhibiting immunomodulatory activity. After stimulation with LL-37, macrophages produce TNF- $\alpha$, while mast cells release various interleukins (IL-2, IL-4 and IL-6). As the sole representative of the cathelicidin family of antimicrobial peptides in humans with immunomodulatory activity, LL-37 contributes to numerous autoimmune diseases, such as atherosclerosis, psoriasis, rheumatoid arthritis and systemic lupus erythematosus. Via the "Unbiased Target Fishing Approach", AKBA binds directly to LL-37 and causes a concentration-dependent inhibition. Therefore, it is believed that AKBA could be a suitable natural remedy for the treatment of diseases related to LL-37 (17).

\section{Inhibition of NF- $\kappa B$}

Since it controls the transcription of a large number of proinflammatory genes and genes related to cell proliferation, nuclear factor $\kappa \mathrm{B}(\mathrm{NF}-\kappa \mathrm{B})$ is involved in the pathogenesis of a large number of diseases and various types of cancer. Numerous studies have reported that AKBA is an inhibitor of NF- $\kappa B$ through various mechanisms. AKBA binds directly to IKB-kinase (IKK) in PC-3 prostate cancer cells and LPS-stimulated human monocytes, consequently inhibiting the NF- $\kappa \mathrm{B}$ signaling pathway and the induction of TNF- $\alpha$. AKBA potentiates TNF-induced apoptosis, suppresses TNF-induced invasion, and inhibits NF- $\kappa \mathrm{B}$ ligand-induced osteoclastogenesis, which is thought to require NF- $\mathrm{NB}$ activation, indicating that it may provide an effective treatment for certain inflammatory diseases (17).

\section{Clinical particulars}

\section{Rheumatoid arthritis}

As discussed in previous section, animal and in vitro studies showed that frankincense extract exhibits prominent anti-inflammatory activity; therefore, it has been suggested as a herbal medicinal substance for potential treatment of rheumatoid arthritis (RA). However, the available publications bring conflicting results with regard to the efficiency of frankincense preparations in monotherapy or in combination products. Currently, there is insufficient evidence to opt either for or against the use of frankincense in RA treatment (12).

In a multicentric, double-blind, placebo-controlled, 12-week pilot trial on 78 participants with the diagnosis of rheumatoid arthritis, a smaller group of patients $(n=37)$ was selected and treated with the standardized frankincense extract $\left(\mathrm{H} 15^{\circledR}\right.$ or placebo, in a daily dose of $3600 \mathrm{mg}$, in addition to their common medication 
(NSAIDs/corticosteroids) $(12,18)$. In the end, only a statistically insignificant decrease in the use of NSAIDs was observed in the group of patients who received $\mathrm{H} 15^{\circledR}$, compared to placebo (5.8\% vs. $3.1 \%)$. The efficacy of the tested extract was not confirmed in pain reduction or function improvement, as measured with validated scales. Also, no differences in mean values of C-reactive protein levels between groups were found (18).

Unfortunately, the power of the test was not calculated in this trial, so it is not clear if the sample size was acceptable to distinguish the true treatment benefits. The methods of blinding and randomization were not well described, so the results of this study cannot be considered definitive (12).

Etzel (1996) published a review of 11 studies conducted between 1985 and 1990, lasting 1-6 months and involving more than 260 patients with juvenile chronic arthritis, active chronic polyarthritis, or rheumatoid arthritis, who were treated with $\mathrm{H} 15^{\circledR}$ (19). The most common study design was direct observation; placebo-controlled and doubleblind studies were also performed, but the details of each study were not provided (12). It was concluded that $\mathrm{H}_{15}{ }^{\circledR}$ improved chronic symptoms such as joint swelling and stiffness compared to placebo; it also reduced NSAID intake by a certain amount. As for the therapeutic benefits, they have been reported to be additive to other treatments, with minimal adverse effects. $\mathrm{H} 15^{\circledR}$ is found to be a disease-modifying agent and it can replace other disease-modifying therapies, with unclear, but positive long-term effects on the joints, anatomic, and functional structures. Early use of $\mathrm{H} 15^{\circledR}$ also appeared to be beneficial.

Chopra et al. (2000) conducted a 16-week randomized, double-blind, placebo controlled parallel clinical trial of therapeutic efficacy of a combination product RA-1 in 182 adult patients of both sexes with rheumatoid arthritis (RA) (20). RA-1 is a traditional formulation consisted of $B$. serrata, Withania somnifera (ashwagandha), Zingiber officinale (ginger) and Curcuma longa (turmeric) purified extracts (extraction and formulation details were not given), which was administered to the participants in the dose of $444 \mathrm{mg} /$ day (2 tablets 3 times a day), with discontinuation of other RA therapies. Therapies by glucocorticoids and disease modifying antirheumatic drugs (DMARD) were ceased a month prior to enrolment, while NSAIDs were not permitted during a one-week washout period and throughout the whole study. Paracetamol (500 mg tablets; monitored use) was allowed as a "rescue analgetic" only. Signs and symptoms of RA, such as joint elasticity, pain, swelling, morning stiffness, etc. were assessed by ACR (American College of Rheumatism) core set $20 \%$ and $50 \%$ of improvement, and ACR $20 \%$ improvement response. Levels of C-reactive protein, rheumatoid factor (RF) and IL-6 in plasma were monitored as well. An intent-to-treat (ITT) analysis was performed (statistical tool that includes data collected from all subjects who underwent randomization, regardless of whether they completed the study or not); the number of participants required to assure at least $80 \%$ of the test power was calculated before the 
beginning of the experiment. Seventeen patients withdrew from the study, but none due to adverse drug reactions or toxicity (20).

In this trial, significant improvements were achieved in both RA-active and placebo groups. The RA-1 results were superior to placebo in numerical sense, but the differences never reached statistical significance, except for a percentage of subjects with a $50 \%$ reduction in swollen joints count and swollen joint score, reduction in levels of rheumatoid factor (30\% reduction vs. $0 \%$, respectively) and relative improvement in the ACR 20\% assessment score (39\% vs. 30\%, respectively) (20).

Although comprehensive and well-designed, this trial failed to provide stronger evidence of RA-1 efficacy, due to mixed statistical significance of the difference between the categories, which was mainly a consequence of an extraordinary and hard to explain placebo response, mostly coming from certain sociological factors and peculiarities of Indian society; therefore, the results of this trial cannot be applied to clinical practice $(12,20)$. For example, rheumatoid factor, an "objective" serologic marker that is less affected by the "placebo effect", significantly improved in the RA-1 group. Although suggestive, the results remain questionable, but certainly deserve confirmation by additional studies (12).

In a double-blind, randomized, placebo-controlled, crossover trial, the efficacy of Articulin- $\mathrm{F}^{\circledR}$ combination product (100 mg of Boswellia serrata oleo-gum resin, $450 \mathrm{mg}$ of Withania somnifera root, $50 \mathrm{mg}$ of Curcuma longa rhizome and $50 \mathrm{mg}$ of zinc complex per capsule) was assessed in 20 patients with RA (12,21). At a dose of 2 capsules thrice a day, Articulin- $\mathrm{F}^{\circledR}$ and placebo were given to the participants for 3 months. All medications were withdrawn 1 month prior to the study. The subjects were recruited with regard to signs and symptoms of RA, such as morning stiffness, swelling of joints, pain severity, disability or loss of function, and serologically positive rheumatoid factor. Assessment was based on the measurement of stiffness and pain using validated Ritchie articular index, American Rheumatism Association joint score and non-validated scales, ESR (erythrocyte sedimentation rate) and RF. The treatment with Articulin- $\mathrm{F}^{\circledR}$ led to a moderate improvement in all the investigated parameters (grip strength, pain, duration of morning stiffness, and disability score) vs. placebo; the benefits were noticed after two weeks of therapy and persisted by the end of the trial. After three months, conversion of RF to seronegativity occurred in 9 patients taking Articulin- $\mathrm{F}^{\circledR}$ and none taking placebo. The use of NSAIDs as rescue medicines in symptom control was necessary in 3 patients taking Articulin- $\mathrm{F}^{\circledR}$ versus 18 receiving placebo. The presented results are encouraging, although there were some issues with randomization and blinding that might introduce bias and confounders into the interpretation of the outcomes. Since Articulin- $\mathrm{F}^{\circledR}$ is a combination product, the isolated effect of frankincense could not be assessed (12). 


\section{Osteoarthritis}

In a double blind, crossover, randomized, placebo-controlled study of 30 patients of either gender older than 40, with clinical and radiological diagnosis of osteoarthritis (OA) of the knee, the participants were given a proprietary product Cap-Wokvel ${ }^{\circledR}$ containing $333 \mathrm{mg}$ of standardized B. serrata oleo-gum resin extract per capsule, or placebo (starch), thrice a day for eight weeks. After a washout period, the crossover was done and the patients were given the opposite of previous treatment for additional eight weeks. (12,22). In all patients, the intensity of swelling, severity of pain and improvement of function was assessed at the beginning of the study, at the end of the first phase, as well as at the beginning and the end of the second phase, after the crossover. All patients reported a decrease in pain, increase in knee flexion, increase in walking range, as well as better kneeling ability, sitting with crossed legs, squatting and stair climbing. However, although the results of this study are encouraging, there are some flaws in the experimental design (description randomization, blinding, and statistical analysis were not provided) that reduce its overall quality (12).

Two studies of similar design (three parallel groups, two intervention groups and one placebo control) and undertaken by the same authors, investigated the efficacy of a proprietary product 5 -Loxin ${ }^{\circledR}$ for a period of 12 weeks $(23,24)$. In these studies, proprietary product 5-Loxin ${ }^{\circledR}$ is described as a novel $B$. serrata extract, containing at least $30 \%$ of AKBA and manufactured using a selective enrichment process (Indian patent No. 205269). The first one, by Sengupta et al. (2002) was a dose-finding study where high $(250 \mathrm{mg} /$ day $)$ and low (100 mg/day) doses were compared (23). The most important finding of this study was that higher and lower doses of 5-Loxin ${ }^{\circledR}$ did not produce significantly distinctive outcomes.

In a subsequent study by the same group of authors (24), the efficacy of 5-Loxin ${ }^{\circledR}$ $\left(100 \mathrm{mg} /\right.$ day) was compared to Aflapin ${ }^{\circledR}$, an alternative proprietary product containing $B$. serrata oleo-gum resin extract. Aflapin ${ }^{\circledR}$ is described in the study as a novel synergistic composition containing $B$. serrata extract selectively enriched with AKBA and $B$. serrata non-volatile oil. The non-volatile oil was prepared using a patented procedure (patent application PCT/IN2009/000505) involving selective removal of boswellic acids followed by removing volatiles under high vacuum. The composition was standardized to contain at least $20 \%$ AKBA (24).

The evidence of the efficacy and safety of 5-Loxin ${ }^{\circledR}$ and Aflapin ${ }^{\circledR}$ administration in subjects with OA was provided. Both formulations significantly improved the function of joints at $100 \mathrm{mg} /$ day, but Aflapin ${ }^{\circledR}$ outperformed 5 -Loxin ${ }^{\circledR}$, rapidly reducing the pain, after just one week of treatment. Aflapin ${ }^{\circledR}$ appeared to be capable of inhibiting cartilage degrading enzyme MMP-3 and to have the potential to regulate the inflammatory component by inhibiting ICAM-1. Finally, both formulations were assessed as safe for long-term supplementation. 
Proprietary product Articulin- $\mathrm{F}^{\circledR}$ was the subject of another complementary, double-blind, randomized, placebo controlled, crossover trial on 42 patients with OA (25), which was designed and conducted essentially the same way as previously described, with the same outcomes (21). At the end of the study, it was shown that the treatment significantly affected both the pain severity and disability scores, as assessed by validated instruments. On the other hand, the influence on morning stiffness, grip strength and joint score, although certain improvement was observed, did not reach a statistical significance, which could be a consequence of the sample size, which was inadequate for detecting true benefits. Other important flaws in the design of this study are unclear randomization and blinding, as well as imprecise inclusion criteria; therefore, the patient population may not have been homogeneous. The mixed statistical significance of the results and the isolated nature of this study leave open the question of the efficacy of Articulin- $\mathrm{F}^{\circledR}$ for OA (12).

\section{Bronchial asthma}

The efficacy of B. serrata oleo-gum resin was assessed in a 6-week, randomized, double-blind, placebo-controlled study on 80 patients with bronchial asthma, who received an oral dose of either $300 \mathrm{mg}$ of powdered $B$. serrata oleo-gum resin (Scompound $^{\mathbb{R}}$ ) or lactose (as placebo), thrice daily $(12,26)$. On days 1 and 42 , clinical and laboratory examinations were performed, and a record of asthma exacerbations was kept. The improvements were observed in both groups for multiple parameters. The improvement in spirometric parameters (forced expiratory volume during the first second - FEV1) was $25 \%$ in the group taking frankincense oleo-gum resin, as opposed to $5 \%$ in the placebo group. However, the basal mean value of FEV1 in the treatment group was $20 \%$ lower than in the control group, so the values in both groups were near equivalent by the end of the study. The mean value of forced vital capacity (FVC) improved by $21 \%$ in the treatment group vs. $9 \%$ in the control. Secondary effects of the treatment, such as reduced dyspnea and eosinophilia, as well as the absence of rhonchus (a loud, wheezing sound heard on auscultation), were also evident in the treatment group. The number of asthma exacerbations was also significantly reduced in the treatment group. These results are in line with previous findings that constituents of frankincense are involved in the control of biochemical progression of asthmatic bronchoconstriction via the inhibition of leukotriene biosynthesis. However, a significant difference in baseline features of control and treatment groups was observed, raising questions about the quality of randomization and casting doubt on overall comparability of the groups.

\section{Crohn's disease}

Gerhard et al. (2001) carried out a double-blind randomized equivalence trial using the standardized $B$. serrata oleo-gum resin extract $\left(\mathrm{H} 15^{\circledR}, 1200 \mathrm{mg} 3\right.$ times a day) or mesalazine (1500 mg 3 times a day) during eight weeks in 102 patients with the diagnose of active Crohn's disease (CD) $(12,27)$. The primary treatment outcome measure was the 
Crohn's Disease Activity Index (CDAI), a research tool frequently used in medical research to quantify the multiple signs and symptoms of $\mathrm{CD}$ in affected patients. Moderate improvements in the CDAI were observed in both groups by the end of the study, with greater, but statistically insignificant, improvements in the group of participants who received $\mathrm{H} 15^{\circledR}$.

This study was performed with numerous flaws in the design. Firstly, no power calculation has been performed, so it remains imprecise if the lack of significance of the mean scores difference between the groups was a consequence of genuine comparability of the two therapies, or of insufficient sample size. Also, there was no placebo group in the trial, so the improvements in the CDA Index in the herbal treatment group vs. baseline could not be distingushed from the course of the disease. Furthermore, the procedures of blinding and randomization were not described. Taking into account that 19 participants dropped out of the study ( 6 from the group receiving $H 15^{\circledR}$ and 13 from the group receiving mesalazine), it remained unclear if an ITT analysis was performed at all. Although the results of this study are promising, their clinical relevance is questionable due to its methodological flaws (12).

Holtmeier et al. (2011) conducted a multicentric, 52-week, double-blind, placebocontrolled, randomized, parallel study of efficacy of Boswelan ${ }^{\circledR}(3 \times 2$ soft gelatin capsules/day; $400 \mathrm{mg}$ each) on 108 patients with $\mathrm{CD}$ in remission (28). Boswelan ${ }^{\circledR}$ is produced by extracting the $B$. serrata resin with $80 \%$ ethanol, mixing the obtained fluid extract with propylene glycol monolaurate (type I) and concentrating the mixture to yield an active ingredient of $400 \mathrm{mg}$ native extract (28).

The most important objective of this trial was to find out a percentage of patients who maintained the remission during the 52 weeks of participation. Secondary endpoints were time to relapse, changes of Crohn's Disease Activity Index (CDAI), and Irritable Bowel Disease Questionnaire (IBDQ) scores.

However, this trial was ceased before its planned end, because insufficient distinction between the scores in treatment and placebo groups was reached regarding the primary efficacy endpoint. Boswelan ${ }^{\circledR}$ treatment achieved slightly better results in the treatment group vs. the placebo, as $59.9 \%$ of actively treated patients remained in remission, in contrast to $55.3 \%$ in placebo group. The mean time to relapse was shorter in the active group than in the placebo (171 days vs. 185 days, respectively). With respect to CDAI, IBDQ, and laboratory tests on inflammation, no advantages were detected in favor of Boswelan ${ }^{\circledR}$ treatment. At the same time, no safety concerns related to Boswelan ${ }^{\circledR}$ administration were observed, which affirmed good tolerability of this preparation in long-term treatment of $\mathrm{CD}$; however, it failed to demonstrate a significant efficacy vs. placebo (28). 


\section{Ulcerative colitis}

In an open, non-randomized, 6-week equivalence study in patients with chronic colitis $(\mathrm{n}=30,18-48$ years of age), the participants received either $900 \mathrm{mg}$ of $\mathrm{S}$ compound $^{\circledR}$ or $3 \mathrm{~g}$ of sulfasalazine daily, in 3 divided doses $(12,29)$. The outcomes of therapy were assessed by sigmoidoscopy, rectal biopsy histopathology and stool examinations, as well as measurements of biochemical parameters ( $\mathrm{Hgb}, \mathrm{Fe}, \mathrm{Ca}, \mathrm{P}$, plasma proteins, total leukocytes and eosinophils counts). The values obtained are included in the formula for determining the "remission rate", albeit the authors omitted to provide details both on this formula and calculations. They found that a great majority of patients who received frankincense oleo-gum resin entered "remission" (18/20, or as much as $90 \%$ ), as opposed to the sulfasalazine group $(6 / 10$, or $60 \%)$, but the difference in mean scores between the groups never reached statistical significance. In histological terms, an improvement was observed in $75 \%$ of patients receiving frankincense resin, as opposed to $40 \%$ in the sulfasalazine-treated group - again without statistical significance between the mean values of the groups. With all these limitations, it appears that the mentioned results cannot be interpreted clinically. The authors reported a statistically significant increase in "remission rate" and an improvement in histopathological findings in frankincense-treated group compared to baseline before therapy; however, comparisons with the control group were insignificant. No power of a test calculation was performed, so it remains blurred if the lack of significance was a consequence of real comparability of the two therapies, or the insufficiency of the sample size. Finally, there was no placebo group in the design of the experiment, so the improvements relative to the basal value could not be distinguished from the course of the disease. The lack of blinding introduced a high probability of bias into the results, and the lack of randomization - a chance for confounding (12).

\section{Collagenous colitis}

In a multicentric, placebo-controlled, randomized, double-blind, 6-week clinical study on the response of patients with clinical and histological confirmation of collagenous colitis to administration of $B$. serrata oleo-gum resin extract, the participants ( $\mathrm{n}=31$, aged 18 to 80 years), were randomly allocated to receive either the treatment (1200 $\mathrm{mg}$ of the extract daily, divided in three doses) or an equivalently formulated placebo. The volunteers were excluded from the study if they had received any antiinflammatory therapy (NSAIDs or salicylates), antibiotics and antifungal medicines (ketoconazole), corticosteroids or gastrokinetic agents at least 4 weeks prior to randomization, or if they had infectious diarrhea, earlier colon surgery, confirmed intolerance to frankincense constituents, or were pregnant/lactating. The primary criterion was clinical remission after 6 weeks (less than 3 stools per day), while the secondary endpoints encompassed progress in histological findings and quality of life assessment. ITT-analysis showed that no significant effect vs. placebo had been gained in achieving 
clinical remission, suggesting that larger trials are necessary to determine the clinical efficacy of $B$. serrata oleo-gum resin extract in collagenous colitis (30).

\section{Irritable bowel syndrome}

In a supplement study by Belcaro et al., Casperome ${ }^{\circledR}$, a new and innovative formulation of purified $B$. serrata oleo-gum resin extract, standardized to contain at least $25 \%$ of total triterpenoid acids, with the addition of lecithin-based liposomes to enhance bioavailability after ingestion, was offered to healthy participants with symptoms of idiopathic irritable bowel syndrome (IBS) (31). Besides, the other subjects in this investigation have been offered to decide between the use of hyoscine butylbromide (Buscopan ${ }^{\circledR}$, administered when needed) or a mixture of papaverine hydrochloride $10 \mathrm{mg}$ and Atropa belladonna extract $10 \mathrm{mg}$ (Antispasmina colica ${ }^{\circledR}$; also administered when needed). The group of participants who opted for supplementation with Casperome ${ }^{\circledR}$, received 1 tablet à $250 \mathrm{mg} /$ day, for 4 weeks. Abdominal pain, altered movements of the bowel, meteorism and cramps as predominant symptoms of IBS were evaluated at admittance and at the end of the observational period. Also, the numbers of participants who needed rescue medication or medical assistance were recorded, as well as potential adverse events. By the end of the observation period, it was concluded that IBS symptoms had improved in all groups, but the number of subjects who needed medical attention or rescue medication significantly decreased only in Casperome ${ }^{\circledR}$ group. The administration of Casperome ${ }^{\circledR}$ led to a lower incidence of side effects (constipation), suggesting that it could be an encouraging approach to IBS salving (31).

In a subsequent prospective, controlled, randomized clinical trial on Casperome ${ }^{\circledR}$ by Riva et al., 69 strictly selected healthy participants with mild IBS were assigned either to the standard management group (diet and Buscopan ${ }^{\circledR}$ or Antispasmina colica ${ }^{\circledR}$ if needed) or Casperome ${ }^{\circledR}$-receiving group (one $250 \mathrm{mg}$ tablet daily). At admittance, after 3 and 6 months, prevalent IBS signs and symptoms (recurring and abdominal pain at pressure, altered movements of the bowel, flatulence and spontaneous cramps) were selfassessed. The numbers of patients who needed rescue medication (Buscopan ${ }^{\circledR}$ Compositum) and who experienced any kind of adverse effects were also recorded. At the 6-month follow-up assessment, in the Casperome ${ }^{\mathbb{R}}$-supplemented group, the selfassessed values for almost all symptoms of IBS were lower in comparison to the standard management group, as well as the need for rescue medications and medical assistance. Albeit infrequent, constipation was described as the main adverse event. It was significantly more frequent in the group of participants who received standard medication (32).

\section{Musculoskeletal disorders}

In an open label, registry, supplement study by Franceschi et al. (2016), the safety and efficacy of Casperome ${ }^{\circledR}$ in the supportive management of musculoskeletal disorders was assessed in 52 healthy young sportsmen with acute knee pain and inflammation, who 
were offered to join either a control group (standard pain management) or supplement group (Casperome ${ }^{\circledR}, 250 \mathrm{mg} /$ day) and follow 4-week protocols. This registry study revealed that Casperome ${ }^{\circledR}$ supplementation led to an improvement in all the tested parameters associated with osteo-muscular pain and inflammation, as well as the need for rescue drugs and medical attention (33).

Several succeeding randomized clinical trials showed that Casperome ${ }^{\circledR}$ was effective in a whole array of parameters that distinguish musculoskeletal disorders, like the overuse injury of the Achilles tendon, tennis elbow (epicondylitis), radiculopathies, twists of ankles and sport injuries. In all trials, a reduction of pain and improvement of functional capabilities of joints and adjacent tissues occurred almost promptly. Notably, the improvements came along with lower levels of inflammatory markers in plasma, as well as with a weaker need for taking rescue medication (analgetics) (34).

\section{Conclusions}

The reviewed articles show that $B$. serrata oleo-gum resin extracts exhibit beneficial effects that could be relevant for their use in pharmacological treatment of various ailments, such as rheumatoid and osteoarthritis, bronchial asthma, Crohn's disease and irritable bowel syndrome, ulcerative and collagenous colitis, as well as various musculoskeletal disorders.

The active constituents of $B$. serrata oleo-gum resin are boswellic acids (3-Oacetyl-11-keto- $\beta$-boswellic acid, AKBA in particular), which are responsible for the observed anti-inflammatory activity. They obstruct the cytokine (IL-1 $\beta$, IL-6 and TNF$\alpha$ ) and PGE 2 biosynthesis, and hinder the activities of HLE, LL-37 and transcription factor $\mathrm{NF}-\kappa \mathrm{B}$.

The available data are still insufficient to elect for the use of treatment by different frankincense preparations as clinically proven. Being still under-investigated, this area remains open for further considerations, as the clinical trials performed so far have often been based on erroneous research design, inadequate definition of the herbal treatment outcome, unclear and/or incomplete inclusion criteria for participants, or even manipulation of experimental data to support the expected results.

However, it may be concluded that the knowledge on anti-inflammatory activity of frankincense is growing. As of this moment, it seems reasonable to predict the advent of efficient and safe frankincense-based herbal medicinal products in the near future. 


\section{References}

1. Ben-Yehoshua S, Borowitz C, Hanuš LO. Frankincense, Myrrh, and Balm of Gilead: Ancient Spices of Southern Arabia and Judea. In: Janick J, editor. Horticulture Reviews 39. Hoboken (NJ): John Wiley \& Sons, Inc.; 2012; p. 1-76.

2. Anonymous. Boswellia serrata. Alt Med Rev. 2008;13(2):165-7.

3. Engels G. Frankincense. HerbalGram - The Journal of the American Botanical Council. 2010;88:14.

4. McCutcheon A. Adulteration of Boswellia serrata. Austin, TX: Botanical Adulterants Prevention Program; Botanical Adulterants Bulletin. 2018.

5. Incense Route - Desert Cities in the Negev [Internet]. Paris: UNESCO, World Heritage Centre; [cited 2020 Oct 31]. Available from: https://whc.unesco.org/en/list/1107/

6. Basar S. Phytochemical Investigations on Boswellia Species. Comparative Studies on the Essential Oils, Pyrolysates and Boswellic Acids of Boswellia carterii Birdw., Boswellia serrata Roxb., Boswellia frereana Birdw., Boswellia neglecta S. Moore and Boswellia rivae Engl. [dissertation]. [Hamburg (DE)]: University of Hamburg; 2005. 238 p.

7. World Health Organisation. WHO Monographs on Selected Medicinal Plants, Vol. 4, World Health Organisation, Geneva, 2009.

8. Hamidpour R, Hamidpour S, Hamidpour M, Hamidpour R. Frankincense (Boswellia Species): The Novel Phytotherapy for Drug Targeting in Cancer. Arch Cancer Res. 2016;4(1):1-5.

9. Ridha Mustafa Al-Yasiry A, Kiczorowska B. Frankincense - therapeutic properties. Postepy Hig Med Dosw (online). 2016;70:380-91.

10. Siddiqui MZ. Boswellia serrata, a Potential Antiinflammatory Agent: An Overview. Indian J Pharm Sci. 2011 May;73(3):255-61.

11. European Pharmacopoeia. $8^{\text {th }}$ ed, Strasbourg: Council of Europe, 2013; 2128-9.

12. Basch E, Boon H, Davies Heerema T, Foppo I, Hashmi S, Hasskarl J et al. Boswellia: An EvidenceBased Systematic Review by the Natural Standard Research Collaboration. J Herb Pharmacother. 2004;4(3):63-83.

13. Public Summary of Positive Opinion for Orphan Designation of Boswellia serrata resin extract for the treatment of peritumoral oedema derived from the brain tumors - EMEA/COMP/2247/02 Rev.1 [Internet]. London: European Medicines Agency. c2007 [cited 2020 Oct 2]. Available from: https://www.ema.europa.eu/en/documents/orphan-designation/eu/3/02/117-public-summarypositive-opinion-orphan-designation-boswellia-serrata-resin-extract-treatment_en.pdf, February 2007.

14. Kar A, Menon MK. Analgesic effect of the gum resin of Boswellia serata Roxb. Life Sci. 1969;8(19):1023-8.

15. Kapil A, Moza N. Anticomplementary activity of boswellic acids, an inhibitor of C3-convertase of the classical complement pathway. Int J Immunopharmacol. 1992;14:1139-43.

16. Knaus U, Wagner H. Effects of boswellic acid of Boswellia serrata and other triterpenic acids on the complement system. Phytomedicine. 1996;3(1):77-80.

17. Yin Q, Bai J, Sun Y, Wang Z, Wang H. Functions and Mechanisms of AKBA in Inflammation Diseases and Cancer. J Immunol Res Ther. 2017;2(1):81-9. 
18. Sander O, Herborn G, Rau R. Ist H15 (Harzextrakt von Boswellia serrata, "Weihrauch") eine sinnvolle Ergänzung zur etablierten medikamentösen Therapie der chronischen Polyarthritis? Ergebnisse einer doppelblinden Pilotstudie [Is H15 (resin extract of Boswellia serrata, "incense”) a useful supplement to established drug therapy of chronic polyarthritis? Results of a double-blind pilot study]. Z Rheumatol. 1998;57(1):11-6. German.

19. Etzel R. Special extract of Boswellia serrata (H15) in the treatment of rheumatoid arthritis. Phytomed. 1996;3(1):91-4.

20. Chopra A, Lavin P, Patwardhan B, Chitre D. Randomized double blind trial of an ayurvedic plant derived formulation for treatment of rheumatoid arthritis. J Rheumatol. 2000;27(6):1365-72.

21. Kulkarni RR, Patki PS, Jog VP, Gandage SG, Patwardban B. Efficacy of an Ayurvedic formulation in rheumatoid arthritis: A double-blind, placebo-controlled, cross-over study. Indian J Pharm. 1992;24:98-101.

22. Kimmatkar N, Thawani V, Hingorani L, Khiyani R. Efficacy and tolerability of Boswellia serrata extract in treatment of osteoarthritis of knee-a randomized double blind placebo controlled trial. Phytomedicine. 2003;10(1):3-7.

23. Sengupta K, Alluri KV, Satish AR, Mishra S, Golakoti T, Sarma KV, Dey D, Raychaudhuri SP. Arthritis Res Ther. 2008;10(4):R85.

24. Sengupta K, Krishnaraju AV, Vishal AA, Mishra A, Trimurtulu G, Sarma KVS, et al. Comparative efficacy and tolerability of 5-Loxin ${ }^{\circledR}$ and Aflapin ${ }^{\circledR}$ against osteoarthritis of the knee: A double blind, randomized, placebo controlled clinical study. Int J Med Sci. 2010;7(6):366-77.

25. Kulkarni RR, Patki PS, Jog VP, Gandage SG, Patwardhan B. Treatment of osteoarthritis with a herbomineral formulation: a double-blind, placebo-controlled, cross-over study. J Ethnopharmacol. 1991;33(1-2):91-5.

26. Gupta I, Gupta V, Parihar A, Gupta S, Lüdtke R, Safayhi H, Ammon HP. Effects of Boswellia serrata gum resin in patients with bronchial asthma: results of a double-blind, placebo-controlled, 6-week clinical study. Eur J Med Res. 1998;3(11):511-4.

27. Gerhardt H, Seifert F, Buvari P, Vogelsang H, Repges R. Therapie des aktiven Morbus Crohn mit dem Boswellia-serrata-Extrakt H 15 [Therapy of active Crohn disease with Boswellia serrata extract H 15]. Z Gastroenterol. 2001;39(1):11-7. German.

28. Holtmeier W, Zeuzem S, Preiss J, Kruis W, Böhm S, Maaser C, Raedler A, Schmidt C, Schnitker J, Schwarz J, Zeitz M, Caspary W. Randomized, placebo-controlled, double-blind trial of Boswellia serrata in maintaining remission of Crohn's disease: good safety profile but lack of efficacy. Inflamm Bowel Dis. 2011;17(2):573-82.

29. Gupta I, Parihar A, Malhotra P, Gupta S, Lüdtke R, Safayhi H et al. Effects of gum resin of Boswellia serrata in patients with chronic colitis. Planta Med. 2001;67(5): 391-5.

30. Madisch A, Miehlke S, Eichele O, Mrwa J, Bethke B, Kuhlisch E et al. Boswellia serrata extract for the treatment of collagenous colitis. A double-blind, randomized, placebo-controlled, multicenter trial. Int J Colorectal Dis. 2007;22(12):1445-51.

31. Belcaro G, Gizzi G, Pellegrini L, Corsi M, Dugall M, Cacchio M et al. Supplementation with a lecithin-based delivery form of Boswellia serrata extract $\left(\right.$ Casperome $\left.^{\circledR}\right)$ controls symptoms of mild irritable bowel syndrome. Eur Rev Med Pharmacol Sci. 2017;21(9):2249-54. 
32. Riva A, Giacomelli L, Togni S, Franceschi F, Eggenhoffner R, Zuccarini MC, Belcaro G. Oral administration of a lecithin-based delivery form of boswellic acids $\left(\right.$ Casperome $\left.{ }^{\circledR}\right)$ for the prevention of symptoms of irritable bowel syndrome: a randomized clinical study. Minerva Gastroenterol Dietol. 2019;65(1):30-35.

33. Franceschi F, Togni S, Belcaro G, Dugall M, Luzzi R, Ledda A et al. A novel lecithin based delivery form of Boswellic acids $\left(\right.$ Casperome $\left.^{\circledR}\right)$ for the management of osteo-muscular pain: a registry study in young rugby players. Eur Rev Med Pharmacol Sci. 2016;20(19):4156-61.

34. Riva A, Allegrini P, Franceschi F, Togni S, Giacomelli L, Eggenhoffner R. A novel boswellic acids delivery form $\left(\right.$ Casperome $\left.{ }^{\circledR}\right)$ in the management of musculoskeletal disorders: a review. Eur Rev Med Pharmacol Sci. 2017;21(22):5258-63. 


\section{O tamjanu}

\section{(Olibanum, Boswellia spp., Burseraceae)}

\section{Zoran Maksimović*}

\section{Univerzitet u Beogradu - Farmaceutski fakultet, Katedra za farmakognoziju, Vojvode Stepe 450, 11221 Beograd, Srbija}

*Autor za korespondenciju: E-mail: zmaksim1@pharmacy.bg.ac.rs

\section{Kratak sadržaj}

Vrste roda Boswellia (Burseraceae) su žbunovi ili nisko drveće, čiji areal rasprostranjenja obuhvata veliki geografski prostor između severne Afrike i Indije. Nakon zasecanja, njihova kora oslobađa oleogumirezinu, koja je poznata pod nazivom tamjan (Olibanum). U tradicionalnoj medicini, koristi se u lečenju artritisa, astme, ulcerativnog kolitisa, kašlja i ozleda. Različiti preparati tamjana se u prometu nalaze gotovo isključivo u obliku dodataka ishrani (dijetetskih suplemenata). Indijski tamjan ili Olibanum indicum je oficinalan u Evropskoj farmakopeji.

Glavni sastojci tamjana su bosvelinske kiseline, među kojima je najznačajnija i najzastupljenija 3-O-acetil-11-keto- $\beta$-bosvelinska kiselina (AKBA). AKBA je inhibitor 5-lipoksigenaze i ispoljava antiinflamatorni i antiartritički efekat. Pored toga, tamjan sadrži etarsko ulje, čiji sastav u velikoj meri zavisi od biološkog izvora, kao i arabinogalaktane i glikoproteine.

Malim kliničkim studijama je potvrđen izvestan pozitivan efekat raznih preparata tamjana na ulcerativni kolitis, bronhijalnu astmu, blage simptome sindroma iritabilnog kolona i poremećaje koštano-mišićnog sistema. Međutim, kod kolagenoznog kolitisa ili za održanje remisije Kronove bolesti, dokazi su nejasni ili izostaju. Ekstrakt bogat AKBA se pokazao efikasnim kod pacijenata sa osteoartritisom i, u izvesnoj meri, reumatoidnim artritisom. Skoro sva objavljena klinička ispitivanja su imala ozbiljne nedostatke u eksperimentalnom dizajnu, kao što su mala veličina uzorka i nekompletno objavljivanje eksperimentalnih podataka. Neophodne su veće i bolje dizajnirane studije kako bi se ostvarile preporuke za primenu u kliničkoj praksi.

Ključne reči: Boswellia, tamjan, bosvelinske kiseline, antiinflamatorno delovanje. 